Emotional School Engagement and Global Self-Esteem in Adolescents:

Genetic Susceptibility to Peer Acceptance and Rejection

According to the bioecological model, human development results from the interaction between an individual and his or her environment (Bronfenbrenner \& Morris, 2008). Substantial research has focused on the different ecological contexts wherein an individual develops. Peers become increasingly important during development (Gifford-Smith \& Brownell, 2003) and are crucial for adolescents' well-being (Viner et al., 2012). Numerous studies have shown associations between the peer context and maladaptation and psychopathology (Hawker \& Boulton, 2000; La Greca \& Harrison, 2005) whereas less attention has been given to positive emotional development. The current study focuses on global self-esteem and emotional school engagement, as important aspects of adolescents' emotional functioning.

In addition to the ecological context, Bronfenbrenner has also recognized the importance of biological resources in human development (Bronfenbrenner \& Morris, 2008; Ceci, 2006). Twin studies revealed that a large portion of the variability in self-esteem (i.e., approximately 40\%) can be explained by genetic factors (Kamakura, Ando, \& Ono, 2007; Neiss, Sedikides, \& Stevenson, 2002). Nevertheless, research aiming to reveal the genetic underpinnings of self-esteem, emotional school engagement, or other positive developmental outcomes is limited and the precise genetic underpinnings of this heritability need to be further explored. A promising candidate polymorphism (i.e., inter-individual differences in DNA base sequences) to consider is 5-HTTLPR, which is a polymorphism in the serotonin transporter gene. This polymorphism has been associated with several positive outcomes, such as, subjective well-being (De Neve, 2011).

In line with Bronfenbrenner's bioecological theory, development can be considered as the result of a gene-environment interaction. More specifically, a high genetic vulnerability 
can make individuals susceptible to both adverse and beneficial environments, which is a certain type of gene-environment interaction referred to as differential susceptibility (Belsky, 2013).

This study aims to provide more insight into how indices of positive emotional functioning (i.e., global self-esteem and emotional school engagement) are shaped by (a) peer acceptance and rejection, (b) frequencies in 5-HTTLPR alleles, and (c) the interaction of both factors. We thus adopted a gene-by-environment $(\mathrm{G} \times \mathrm{E})$ research design and examined the differential susceptibility hypothesis.

\section{Peer Acceptance and Rejection}

Peer relationships change when children grow older. In adolescence, peer relationships gain in importance which is demonstrated by a substantial increase in the time spent with peers (Gifford-Smith \& Brownell, 2003; Larson \& Richards, 1991). The peer context comprises different interactions between individuals who are close in age (Kindermann, Zimmer-Gembeck, \& Duffy, 2010). Studies that investigate the effect of group-based peer constructs often focus on sociometric categories or composite measures of acceptance and rejection (i.e., social preference; Buhs, Ladd, \& Herald, 2006). However, the present study examined the effects of peer acceptance and rejection separately in order to distinguish between positive and negative peer effects.

Peer acceptance and rejection refer to the relative position of an adolescent within a group (often the classroom) in terms of likeability (Gifford-Smith \& Brownell, 2003). Hence, peer acceptance and rejection refer to the degree of how much the class group respectively likes or dislikes the adolescent (Gifford-Smith \& Brownell, 2003; Waas, 2006). To measure peer acceptance and rejection, the most commonly used method is a peer nomination procedure (Gifford-Smith \& Brownell, 2003; Maassen, van Boxtel, \& Goossens, 2005; Waas, 2006), developed by Coie et al. (1982). In this procedure, peer acceptance and peer rejection 
are measured by asking students the following questions about their classmates: "Whom do you like most?" and "Whom do you like least?", respectively. The underlying assumption of this procedure is that peer acceptance and rejection are two separate dimensions and, as a consequence, do not necessarily represent opposite poles of a common continuum (Coie et al., 1982; Rubin, Bukowski, \& Parker, 2006). The two dimensions typically show a moderate negative correlation (e.g., Hughes \& Im, 2016, found a correlation $r=-.37$ ). In addition, peer acceptance and rejection do not necessarily affect development in similar ways. Hughes and Im (2016), for example, state that disliked children are more actively rejected (ignored, excluded, or ridiculed) by their peers than children who receive few liked most nominations, which makes actively disliked children more prone to develop long-term problems. In addition, negative relational experiences have generally been shown to have a greater impact than positive ones (Baumeister, Bratslavsky, Finkenauer, \& Vohs, 2001).

\section{Peers and Emotional School Engagement}

According to Wehlage, Rutter, Smith, Lesko, and Fernandez (1989, p. 17), school engagement is "the psychological investment required to comprehend and master knowledge and skills explicitly taught in schools". This broad construct is typically described in terms of multiple dimensions (Fredricks, Blumenfeld, \& Paris, 2004; Skinner, Furrer, Marchand, \& Kindermann, 2008). In general, three dimensions of school engagement can be distinguished, that is, behavioral, emotional, and cognitive engagement (Fredricks et al., 2004; Jimerson, Campos, \& Greif, 2003; Ladd \& Dinella, 2009). The current study focuses on emotional engagement, which is defined as students' emotional involvement in and feelings towards learning activities (Meyer \& Turner, 2002; Skinner \& Pitzer, 2012). Emotional engagement is important for adolescents given the association with both academic and nonacademic outcomes. 
Concerning academic outcomes, emotional engagement contributes to students' sustained motivation (Skinner et al., 2008) and learning (Sagayadevan \& van Jeyaraj, 2012), and diminishes the risk of dropout (Fredricks et al., 2004). With regard to nonacademic outcomes, Li and Lerner (2011), for example, found that adolescents who experienced more favorable trajectories of emotional engagement, tend to show less feelings of depression, less drug abuse, and less involvement in delinquent behavior.

Some studies have found associations between peer relationships and school engagement (Pietarinen, Soini, \& Pyhältö, 2014). More specifically, a sense of relatedness to peers contributes to emotional school engagement (Furrer \& Skinner, 2003). Moreover, Lubbers, Van Der Werf, Snijders, Creemers, and Kuyper (2006) found a positive association between peer acceptance and school engagement in adolescents. Peer rejection in early adolescence, in turn, was negatively associated with school bonding (Davidson, Gest, \& Welsh, 2010), which is an aspect of emotional engagement (Fredricks et al., 2004). One study found a positive association between peer acceptance and emotional engagement in specific (Engels et al., 2017). However, more research on the specific associations between peer acceptance or peer rejection and emotional school engagement is scarce. Therefore, the present study aims to fill this gap in the literature.

\section{Peers and Global Self-Esteem}

Self-concept is described as a multidimensional and hierarchical construct comprising self-evaluations in different domains with global self-esteem, or the general evaluation of oneself as a person, situated at the apex (Marsh, 1992). Research already revealed a lot of beneficial consequences of high self-esteem, such as increases in positive affect and decreases in negative affect, relationship satisfaction, and physical health (Orth, Robins, \& Widaman, 2012). In contrast to the numerous positive outcomes of high self-esteem, low self-esteem is associated with different internalizing problems such as rumination (Di Paula \& Campbell, 
2002) and feelings of loneliness in adolescence (Vanhalst, Luyckx, Scholte, Engels, \& Goossens, 2013). Lower self-esteem also predicts depression in adolescence and young adulthood (Orth, Robins, \& Roberts, 2008; Orth et al., 2012; Robins, Donnellan, Widaman \& Conger, 2010; Sowislo \& Orth, 2013) as well as anxiety (Sowislo \& Orth, 2013).

In sum, these findings indicate the importance of global self-esteem for adolescents' development. The present study examined whether peer acceptance and peer rejection are associated with global self-esteem. Several studies have investigated the associations between peer acceptance and adolescents' global self-esteem. For example, Birkeland, Breivik, and Wold (2014) found that perceived peer acceptance positively predicts adolescents' global selfesteem. In addition, peer acceptance can protect students' global self-esteem from the negative impact of a less close relationship with their parents. Furthermore, a study of Leary, Cottrell, and Phillips (2001) also indicated that perceived peer acceptance affects self-esteem in a positive way. Nevertheless, these studies are limited and often use a self-perceived peer acceptance measure, which may lead to shared response bias when used in combination with other self-report measures. Regarding negative peer effects, a study of Thomaes et al. (2010) showed that peer disapproval predicts decreases in children's global self-esteem. However, up till now, no previous study has investigated the association between peer rejection and adolescents' global self-esteem.

\section{Gene-Environment Interactions: 5-HTTLPR}

The concept of gene-environment interactions refers to the extent to which the effect of an environmental factor on a certain developmental outcome is moderated by an individual's genotype (Brendgen, 2012; Johnson, 2007). The prevailing view on geneenvironment interactions is that some people have particular gene variants that make them more prone for negative developmental outcomes in case of an unsupportive environment, but also more prone to positive developmental outcomes in a supportive environment 
(Bakermans-Kranenburg and van IJzendoorn, 2007). This hypothesis is called the differential susceptibility hypothesis and refers to individual differences in reactivity to both adverse and beneficial environmental factors (Belsky, Bakermans-Kranenburg, \& van IJzendoorn, 2007; Ellis, Boyce, Belsky, Bakermans-Kranenburg, \& van IJzendoorn, 2011). This means, more specifically, that in a favorable environment reactive individuals will develop in a more positive way than less reactive individuals, but in an adverse environment the developmental outcomes of the reactive individuals will be more negative (Bakermans-Kranenburg \& van IJzendoorn, 2007; Brendgen, 2012; Ellis et al., 2011).

Empirical evidence for gene-environment interplay is found by investigating the link between an environmental factor, some natural and frequently occurring polymorphisms of a given gene, and variability in certain outcomes of interest (Brendgen, 2012). The current study investigated a specific type of polymorphism, that is, a Variable Number of Tandem Repeats or VNTR, in the serotonin transporter gene (SLC6A4). A VNTR is a short, repeated nucleotide sequence or tandem repeat from which the number varies from individual to individual (Klug, Cummings, Spencer, \& Palladino, 2010). One of the frequently examined VNTRs in SLC6A4 is situated in the promotor region and is referred to as 5-HTTLPR (Caspi et al., 2003; Gillihan et al., 2010). Multiple studies have found main effects of 5-HTTLPR and/or gene-environment interaction effects comprising 5-HTTLPR on emotional problems (Cho et al., 2005; Goossens et al., 2015; Gunthert et al., 2007). More specifically, some studies also examined the moderating role of the serotonin transporter gene promoter polymorphism (5-HTTLPR) in the association between the peer context and emotional problems. For instance, a longitudinal study of Jonassaint et al. (2012) showed that the impact of negative environments in adolescents on self-esteem in adulthood was moderated by 5HTTLPR. Adolescents who lived in poor home and neighborhood conditions and who carried 
the short allele of 5-HTTLPR were more likely to report low self-esteem in young adulthood (Jonassaint et al., 2012).

In a substantial number of studies exhibiting at least one short allele of 5-HTTLPR (i.e., the variant with the smaller number of repeats in the genetic sequence) is considered a risk variant (Caspi et al., 2003; Cho et al., 2005). However, other studies failed to replicate this finding (Margoob \& Mushtaq, 2011; Spithoven et al., 2015).

In addition to its numerous associations with emotional problems, 5-HTTLPR has also been associated with positive psychological functioning in some studies. More specifically, having two long alleles of 5-HTTLPR has been found to be positively associated with, for example, subjective well-being or happiness (De Neve, 2011) and optimism (Fox, Ridgewell, \& Ashwin, 2009). However, the results of some studies also indicated that the short allele is positively associated with positive outcomes. A study of Haase et al. (2015), for example, found a positive association between the short allele and positive emotional expressions. According to Homberg and Lesch (2011), the short allelic genetic variant would have disappeared throughout evolution as a result of natural selection if it would only exert negative effects and bring no benefits. A possible explanation for the maintenance of the short allelic variant of 5-HTTLPR throughout evolution is that the environments people live in determine whether the behavior of the short allele carrier is maladaptive or beneficial (Homberg \& Lesch, 2011). A meta-analysis of van IJzendoorn, Belsky, and BakermansKranenburg (2012) indeed found support to consider the short allele as a susceptibility factor for both positive and negative environments. Keeping in mind the importance of high selfesteem and high emotional school engagement for adolescents, it is relevant to investigate their genetic and environmental associations, both separately and jointly. 


\section{The Current Study}

This study investigated whether peer acceptance and rejection are associated with adolescents' global self-esteem and emotional school engagement, and whether this association is moderated by 5-HTTLPR. A multi-informant (i.e., peers and adolescents) and multi-method (i.e., self-report questionnaires, peer nominations, and saliva sampling) approach was used to collect data. In addition, peer acceptance and rejection were examined separately in order to differentiate between positive and negative peer effects. Given that this is the first study that investigates these associations, we consider our analyses as exploratory in nature. Nevertheless, based on the literature about related topics, we formulated some tentative hypotheses.

First, based on the available literature, we expected that higher peer acceptance would be associated with higher emotional school engagement and higher global self-esteem. Peer rejection, on the other hand, was expected to predict lower emotional school engagement and lower global self-esteem. Second, a gene-environment interaction in accordance with the differential susceptibility hypothesis was expected. We hypothesized that the previously described main effects of peer acceptance and peer rejection on global self-esteem and emotional engagement would be moderated by 5-HTTLPR. Adolescents who have one or two short alleles of 5-HTTLPR and are being more accepted by their peers, were expected to report higher global self-esteem and more emotional school engagement, compared to those who have two long alleles. In contrast, we expected that the more adolescents with this genotypic variation are rejected by their peers, the lower their global self-esteem and emotional school engagement would be, compared to those who have two long alleles.

\section{Method}

\section{Participants and Procedure}


Data were drawn from the first wave of the ongoing longitudinal XXX (i.e., XXX) project of XXX, in Flanders, the Dutch-speaking part of Belgium. Permission for the study was obtained from the Institutional Review Board of the Faculty of Medicine at XXX (ML7972). A randomized multistage sampling approach was used to select participants. Flemish secondary schools from different provinces were invited to take part in the research project after stratification by educational track. Nine secondary schools participated, and 121 classes from Grades 7 to 9 were randomly selected. A total number of 1,116 adolescents participated from which 5 adolescents were removed from the dataset at Wave 1 because they filled out the questionnaires unreliably. Therefore, the final sample consisted of 1,111 adolescents $\left(M_{\mathrm{age}}=13.79, S D=0.94\right)$, of which $51.1 \%$ were boys. The participating adolescents were in Grade $7\left(36.00 \% ; M_{\text {age }}=12.89, S D_{\text {age }}=0.49\right)$, Grade $8\left(37.40 \% ; M_{\text {age }}=\right.$ $\left.13.85, S D_{\text {age }}=0.48\right)$ or Grade $9\left(26.60 \% ; M_{\text {age }}=14.90, S D_{\text {age }}=0.50\right)$ at Wave 1 . The vast majority of the adolescents in this sample were born in Belgium (92.7\%). With regard to family composition, $79.1 \%$ of the sample lived in a nuclear family. To take into account genetic similarity within families, one adolescent from each pair of siblings $(N=58)$ was removed randomly. As a result, the final study sample comprised 1,053 participants.

Prior to data collection, participating adolescents and their parents signed an active informed consent. During a 50-minute session, adolescents collectively filled out questionnaires under supervision of research assistants. In addition, 1,013 adolescents, from the total number of 1,053 participants, donated a saliva sample for genotyping. This was done at school with the assistance of the researchers.

\section{Measures}

Peer acceptance and rejection. In the Flemish educational system, students are part of a single class group with whom they take courses all day long throughout the school year. Therefore, a within-classroom peer nomination procedure to investigate whether an 
adolescent was being accepted or rejected by his or her classmates was considered to be most suited. Students had to write down the class numbers of their classmates for whom a question linked to peer acceptance (i.e., "Whom do you like most?") and a question linked to peer rejection (i.e., "Whom do you like least?") was most suited. They were allowed to nominate an unlimited number of classmates for the same statement, but self-nominations were not allowed. Subsequently, for every adolescent the number of received nominations for the statement linked to peer acceptance and peer rejection was computed and standardized within classrooms. The use of this kind of nomination procedures is considered a valid measure of sociometric popularity (Rubin et al., 2006).

5-HTTLPR genotyping. The current study focuses on 5-HTTLPR, which consists of different lengths of a repetitive base pair (bp) sequencing due to a 44-bp insertion or deletion (long, "l", with 16 repeat units or short, "s", with 14 repeat units, respectively; Heils et al., 1996; Wray et al., 2009). Oragene DNA collection kits (DNA Genotek; Ontario, Canada) were used to collect saliva samples from which DNA was extracted and 5-HTTLPR was genotyped by means of Polymerase Chain Reaction (PCR) and fragment analysis. The PCR amplification mixture consisted of $12.5 \mu \mathrm{l}$ Master Mix (Promega), $0.5 \mu \mathrm{mol} / \mathrm{L}$ of forward primer (5'-CAACCTCCCAGCAACTCCCTGTA-3'), $0.5 \mu \mathrm{mol} / \mathrm{L}$ of reverse primer (5'GAGGGACTGAGCTGGACAACCAC-3'), 50ng DNA, and $1.5 \mu$ water. The following PCR cycling conditions were successively applied: 5 minutes at $95^{\circ} \mathrm{C}, 35$ cycles of 30 seconds at $95^{\circ} \mathrm{C}$, of 30 seconds at $60^{\circ} \mathrm{C}$, of 90 seconds at $72^{\circ} \mathrm{C}$, and finally 7 minutes at $72^{\circ} \mathrm{C}$. The mixture used in the fragment analysis consisted of $0.5 \mu 1$ PCR product with $0.5 \mu 1$ GeneScan 600 LIZ Size Standard v2.0 (Applied Biosystems), and $10 \mu \mathrm{Hi}$-Di formamide. Fragment analysis was performed for both alleles separately in an ABI 3730xl Genetic Analyzer (Applied Biosystems) after a denaturation of 3 minutes. Results were printed with GeneMarker software Version 1.91 (SoftGenetics, 2010). No deviations from Hardy- 
Weinberg equilibrium were found, which indicated that allele and genotype frequencies in our sample were similar to what would be expected in the population $(p>.98)$. A subdivision was made between adolescents with either two long alleles and adolescents with at least one short allele (i.e., $1 / 1$ vs. s/s and s/l together).

Emotional engagement. Participants' degree of emotional school engagement was assessed using items of the emotional school engagement subscale of the Student Report on Engagement Versus Disaffection with Learning questionnaire (Skinner, Kindermann, \& Furrer, 2008). Participants were asked to respond to these items on a 4-point Likert rating scale ranging from (1) 'not at all true' to (4) 'very true' (5 items, $\alpha=.84$, e.g., "I like to be in class"). Internal consistency of this scale ranges from .61 to .85 as reported by the developers and other users (Fredricks \& McColskey, 2012). Higher mean scores represent greater emotional school engagement.

Global self-esteem. To assess adolescents' global self-esteem, the global scale of the Self-Description Questionnaire II (i.e., SDQ-II, Marsh, Plucker, \& Stocking, 2001) was presented to the participants ( $\alpha=.81$, e.g., "Most of the things I do, I do well"). A reliability generalization study showed strong internal consistency for the global scale of the SDQ-II (Leach, Henson, Odom, \& Cagle, 2006). The items were responded to on a 6-point Likert scale from (1) 'false' to (6) 'true'. A higher mean score represents a higher global self-esteem.

\section{Statistical Analyses}

Hierarchical multiple linear regression analyses were performed in SPSS 23.0. More specifically, regression analyses were conducted for global self-esteem and emotional school engagement separately. The models included three predictors, that is, 5-HTTLPR, peer acceptance or peer rejection, and a gene-by-environment interaction variable. Before the interaction term was computed, the environmental variable was standardized. Furthermore, in every regression analysis, we controlled for adolescents' gender and school grade. 


\section{Results}

\section{Descriptive Statistics}

An overview of bivariate correlations, means, standard deviations, and minimum and maximum values is presented in Table 1 . The correlations between peer rejection and both emotional school engagement and global self-esteem, were negative, significant, and small in size (Cohen, 1988). Both peer acceptance and the genotype classification were not significantly correlated with any of the outcome variables.

\section{Hierarchical Regression Analyses}

Table 2 presents the results of the hierarchical multiple regression analyses. In both Models 1 and 2, gender and grade level together explained a significant portion of the variance in emotional school engagement and global self-esteem. Concerning emotional school engagement, girls reported significantly higher mean levels $(\beta=.10, p=.001)$ and being in a higher grade was significantly associated with less emotional engagement $(\beta=-.16$, $p<.001)$. No gender differences were found between the reported mean levels of global selfesteem. In addition, being in a particular grade was not significantly related to the degree of global self-esteem reported by adolescents.

As can be seen in Table 2 (Model 2), peer rejection contributed significantly to the statistical prediction of both global self-esteem and emotional school engagement. Adolescents who were more rejected by their classmates reported lower global self-esteem ( $\beta$ $=-.11, p<.001)$ and less emotional school engagement $(\beta=-.11, p=.001)$. However, the additional proportion of explained variance in both analyses was small. In contrast, Model 1 revealed that peer acceptance was positively, but not significantly, associated with both emotional school engagement and global self-esteem, and no significant genetic main effects of 5-HTTLPR were found. Moreover, none of the regression models yielded a significant interaction effect between peer rejection or peer acceptance and 5-HTTLPR, nor did adding 
an interaction variable to the model lead to a significantly higher explained variance in the different outcome variables.

\section{Discussion}

This study investigated (a) the associations of peer acceptance and rejection with adolescents' emotional school engagement and global self-esteem and (b) the contribution of the 5-HTTLPR polymorphism on adolescents' emotional school engagement and global selfesteem. In addition, this study adopted (c) a gene-by-environment ( $\mathrm{G} \times \mathrm{E})$ research design that investigates differential susceptibility.

Results showed that peer rejection was negatively associated with adolescents' global self-esteem and emotional school engagement. Adolescents who are more rejected by their classmates tend to report lower global self-esteem and less emotional school engagement. The detrimental associations of peer rejection with emotional school engagement and global selfesteem that were found in this study are in line with previous findings on the crucial role of peers for adolescents' well-being (Rubin et al., 2004), and emotional school engagement (Estell \& Perdue, 2013). Because social relationships are important for adolescents' wellbeing, adolescents who are rejected by their peers may not like to go to school. For example, they do not feel welcomed and loved by their classmates and thus experience a low sense of belonging (Wentzel, Wigfield, \& Miele, 2009). This may result in less positive feelings towards school and learning activities and thus lower emotional school engagement (Davidson et al., 2010; Furrer \& Skinner, 2003). Whereas a previous study found associations between peer disapproval and global self-esteem in children (Thomaes et al., 2010), the current study was, to the best of our knowledge, the first to find an association between peer rejection and global self-esteem in adolescents. This result supports the sociometer model which describes self-esteem as an inner measure of social acceptance. Being rejected by peers threatens someone's need to belong and this threat may result in a decrease in self-esteem 
(Leary, Tambor, Terdal, \& Downs, 1995). In contrast to peer rejection, peer acceptance was not significantly associated with emotional school engagement or global self-esteem.

Because this study is one of the first that distinguished between peer rejection and acceptance and investigated the interrelation between peer acceptance and emotional school engagement, replication studies are highly recommended to obtain greater insight in these topics. Considering the main effects of peer rejection and peer acceptance, which were investigated in separate models, peer rejection seems to have a greater impact on adolescents' global self-esteem and emotional school engagement than peer acceptance. Because experiences of peer acceptance occur more often in adolescence than peer rejection (Dijkstra, Lindenberg, \& Veenstra, 2007), experiencing peer acceptance may be considered more normal and, as a result, has less impact on adolescents' global self-esteem or emotional school engagement. The finding that peer rejection seems to affect both aspects of positive emotional functioning in adolescence more strongly than peer acceptance is in line with the general finding by Baumeister et al. (2001) that negative events have a stronger impact on different outcomes than good events. Therefore, future research could focus specifically on experiences of peer rejection in addition to peer acceptance and on differences between both constructs. In addition, it must be noted that although the associations between peer rejection and both emotional school engagement and global self-esteem were statistically significant, the small effect sizes seem to suggest that the practical relevance of the findings is limited.

Regarding the second aim of this study, no associations were found between 5HTTLPR and global self-esteem or emotional school engagement. Most studies indicate that individuals who have at least one short allele of the 5-HTTLPR polymorphism are more vulnerable for emotional problems, compared to those who have two long alleles (Margoob \& Mushtaq, 2011). However, researchers use different ways to analyze allelic variation in 5HTTLPR and results are mixed. Therefore, it is unclear which grouping scheme is most 
appropriate. More specifically, besides numerous findings that carrying at least one short allele constitutes a risk factor for multiple emotional problems (Margoob \& Mushtaq, 2011), other studies suggest that being homozygous for the short allele confers stronger risk (Kretschmer, Sentse, Dijkstra, \& Veenstra, 2014; Miller et al., 2013; Sugden et al., 2010). We therefore explored whether another allelic subdivision would lead to different results. However, results of additional analyses using different grouping schemes (i.e., short/short vs. short/long and a grouping in three categories: long/long, short/long, and long/long, respectively) yielded the same conclusion as our current analyses, thereby increasing the robustness of our findings regarding the absence of an association between 5-HTTLPR and emotional school engagement and global self-esteem. Nevertheless, it is still possible that the absence of a main effect of 5-HTTLPR may be due to insufficient insight into the genetic underpinnings of global self-esteem and emotional school engagement suggesting the need for more advanced genetic research (e.g., polygenic risk scores that aggregate the effects of multiple genes).

Because no gene-environment interactions were found, the present study failed to find evidence for the differential susceptibility hypothesis, which stated that 5-HTTLPR is a moderator of the effect of peer acceptance and peer on adolescents' emotional adaptation. Nevertheless, the importance of this null finding and the null findings regarding the main effects of 5-HTTLPR for the literature on how 5-HTTLPR is associated with well-being should be acknowledged. More specifically, given that this study is well-powered (i.e., we had a probability of .90 to find a significant effect of a predictor if, in reality, this predictor explains only $1 \%$ of the variance), the null findings of this study suggest that there is no noteworthy effect (GPower 3.1, Faul, Erdfelder, Lang, \& Buchner, 2007).

\section{Limitations and Future Research}


This study has several strengths. A first strength of this study is its large sample that consisted of 1,111 adolescents who were in Grades 7 to 9, attended different schools in Flanders, and followed different educational tracks. Second, a multi-method and multiinformant approach was used. More specifically, a multi-informant (i.e., peers and adolescents) and multi-method (i.e., self-report questionnaires, peer nominations, and saliva sampling) approach was used to collect data. In addition, to fully test the differential susceptibility hypothesis, the whole continuum from negative to positive environments needs to be covered (Belsky \& Pluess, 2016). In the majority of differential susceptibility research, the absence of negative environments (e.g., no maltreatment) is erroneously considered as a positive environment (Belsky, \& Pluess, 2009; Hankin et al., 2011). Therefore, an additional strength of this study is that a purely positive and a purely negative environmental factor were distinguished.

Despite its uniqueness and contributions to the existing literature, it is important to acknowledge the limitations of our study as well. First, its cross-sectional design does not permit to draw conclusions about the direction of genetic and environmental effects on global self-esteem and emotional school engagement in adolescents. More specifically, based on the results of this study, it remains unclear whether peer rejection leads to lower self-esteem or less emotional school engagement or vice versa. Although we considered self-esteem and emotional school engagement as outcome variables, it is possible that lower self-esteem and less emotional school engagement predict future peer rejection. For example, some individuals with low selfesteem may excessively seek reassurance from their peers, while at the same time doubting the reassurance they receive because it is not in line with their negative self-views. Therefore, they may repeatedly ask for reassurance, which might annoy others and ultimately lead to rejection (Joiner, Alfano, \& Metalsky, 1992; Joiner, Katz, \& Lew, 1999). Another mechanism that might link low self-esteem to peer rejection is negative feedback seeking. To verify their negative 
self-views, individuals with low self-esteem might actively seek negative feedback from their peers (Swann, Rentfrow, \& Guinn, 2003), which might result in rejection as well. Emotional school engagement, in turn, might also lead to peer rejection through, for example, deviant behavior. Because adolescents with high emotional school engagement strive to meet schools' expectations, they are less likely to show deviant behavior, such as violence (Resnick et al., 1997). The opposite might be true for adolescents with less emotional school engagement (Li \& Lerner, 2011; Loukas, Ripperger-Suhler, \& Horton, 2009). Because of these deviant behaviors, adolescents with lower levels of emotional school engagement might, in turn, experience more difficulties in establishing peer relationships and be more likely to be rejected by their peers (Coie, Terry, Lenox, Lochman, \& Hyman, 1995; Rubin, Bukowski, \& Parker, 2006). Therefore, a longitudinal study that covers the whole sensitive period of adolescence can add valuable information by allowing researchers to determine the direction of effects and make predictions about the role of adolescents' peer relationships, genes, and their interplay for global self-esteem and emotional school engagement across time.

Second, given that we only controlled for age and gender in our analyses, we cannot rule out the existence of other confounding variables that might explain the associations among our study variables. Therefore, we cannot conclude with certainty that the association between peer rejection and global self-esteem or emotional school engagement reflects the actual relationship between the study variables.

Finally, although genetic association studies according to this candidate gene approach are well established in gene-environment interaction research (Brendgen, 2012), the use of quantitative pathway-based association analyses which fits the idea that heritability results from multiple DNA variants, each of which have a small effect, has recently been advocated (Bralten et al., 2013; Plomin, 2013). More specifically, a new promising GWAS (i.e., Genome Wide Association Study) approach, which focuses on polygenic scores (Belsky \& Israel, 
2014; Belsky \& van Ijzendoorn, 2017) and gene networks, is emerging (Goossens et al., 2015). Future research should consider this approach because it may be more effective in tackling the complexity of the human genome than the prevailing research which focuses on a single polymorphism in a single gene.

\section{Conclusion}

As expected, being rejected by peers was associated with lower global self-esteem and less emotional school engagement. Contrary to our expectations, peer acceptance was not associated with global self-esteem and emotional school engagement. Results regarding the detrimental associations of peer rejection and the limited favorable associations of peer acceptance with emotional school engagement and global self-esteem expand our knowledge about the role of peer relations for positive outcomes in adolescence and call for additional research on the underlying mechanisms of these effects. Unexpectedly, the interplay between peer nominations of peer acceptance and rejection and allelic distributions for 5-HTTLPR did not contribute to the prediction of global self-esteem and emotional school engagement. In addition, although the current study did not find evidence for the differential susceptibility hypothesis, insignificant results from well-powered studies also contribute to the evolving body of evidence regarding gene-environment interactions.

\section{Ethical approval}

All procedures performed in studies involving human participants were in accordance with the ethical standards of the institutional and/or national research committee and with the 1964 Helsinki declaration and its later amendments or comparable ethical standards.

This article does not contain any studies with animals performed by any of the authors.

\section{Informed consent}

Informed consent was obtained from all individual participants included in the study. 


\section{References}

Bakermans-Kranenburg, M. J., \& van IJzendoorn, M. H. (2007). Research review: Genetic vulnerability or differential susceptibility in child development: The case of attachment. Journal of Child Psychology and Psychiatry, 48, 1160-1173. doi:10.1111/j.14697610.2007.01801.x

Baumeister, R. F., Bratslavsky, E., Finkenauer, C., \& Vohs, K. D. (2001). Bad is stronger than good. Review of General Psychology, 5, 323-370. doi: 10.1037//10892680.5.4.323

Belsky, J., Bakermans-Kranenburg, M. J., \& van IJzendoorn, M. H. (2007). For better and for worse: Differential susceptibility to environmental influences. Current Directions in Psychological Science, 16, 300-304. doi:10.1111/j.1467-8721.2007.00525.x

Belsky, J. (2013). Differential susceptibility to environmental influences. International Journal of Child Care and Education Policy, 7, 15-31. doi:10.1007/2288-6729-7-2-15

Belsky, D. W., \& Israel, S. (2014). Integrating genetics and social science: Genetic risk scores. Biodemography and Social Biology, 60, 137-155. doi:10.1080/194855 65.2014 .946591

Belsky, J., \& Pluess, M. (2009). Beyond diathesis stress: Differential susceptibility to environmental influences. Psychological Bulletin, 135, 885-908. doi:10.1037/a0017376

Belsky, J., \& Pluess, M. (2016). Differential susceptibility to environmental influences. In D. Cicchetti (Ed.), Developmental psychopathology ( $3^{\text {rd }}$ ed.). Volume two: Developmental neuroscience (pp. 59-106). New York, NY: Wiley.

Belsky, J., \& van Ijzendoorn, M. H. (2017). Genetic differential susceptibility to the effects of parenting. Current Opinion in Psychology, 15, 125-130. doi:10.1016/j.copsyc.2017.02.021

Birkeland, M. S., Breivik, K., \& Wold, B. (2014). Peer acceptance protects global self-esteem 
from negative effects of low closeness to parents during adolescence and early adulthood. Journal of Youth and Adolescence, 43, 70-80. doi:10.1007/s10964-0139929-1

Bralten, J., Franke, B., Waldman, I., Rommelse, N., Hartman, C., Asherson, P., ... AriasVáquez, A.(2013). Candidate genetic pathways for attention-deficit/hyperactivity disorder (ADHD) show association to hyperactive/impulsive symptoms in children with ADHD. Journal of the American Academy of Child and Adolescent Psychiatry, 52, 1204-1212. doi:10.1016/j.jaac.2013.08.020

Brendgen, M. (2012). Genetics and peer relations: A review. Journal of research on adolescence, 22, 419-437. doi:10.1111/j.1532-7795.2012.00798.x

Bronfenbrenner, U., \& Morris, A. A. (2006). The bioecological model of human development. In R. M. L. W. Damon (Ed.), Handbook of child psychology: Theoretical models of human development (6th ed., Vol. 1, pp. 793-828). Hoboken, NJ: Wiley.

Buhs, E. S., Ladd, G. W., \& Herald, S. L. (2006). Peer exclusion and victimization: Processes that mediate the relationship between peer group rejection and children's classroom engagement. Journal of Educational Psychology, 98, 1-13. doi:10.1037/00220663.98.1.1

Caspi, A., Sudgen, K., Moffit, T. E., Taylor, A., Craig, I. W., Harrington, H., ... Poulton, R. (2003). Influence of life stress on depression: Moderation by a polymorphism in the 5HTT gene. Science, 301, 386-389. doi:10.1126/science.1083968

Ceci, S. J. (2006). Urie Bronfenbrenner (1917-2005). American Psychologist, 61, 173-174. doi:10.1037/0003-066X.61.2.

Cho, H. J., Meira-Lima, I., Cordeiro, Q., Michelon, L., Sham, P., Vallada, H., \& Collier, D. 
A. (2005). Population-based and family-based studies on the serotonin transporter gene polymorphisms and bipolar disorder: A systematic review and meta-analysis. Molecular Psychiatry, 10, 771-781. doi:10.1038/sj.mp.4001663

Cohen, J. (1988). Statistical power analysis for the behavioral sciences (2nd ed.). Hillsdale, NJ: Erlbaum.

Coie, J. D., Dodge, K. A., \& Coppotelli, H. (1982). Dimensions and types of social status: A cross-age perspective. Developmental Psychology, 18, 557-570. doi:10.1037//00121649.18.4.557

Coie, J., Terry, R., Lenox, K., Lochman, J., \& Hyman, C. (1995). Childhood peer rejection and aggression as predictors of stable patterns of adolescent disorder. Development and Psychopathology, 7, 697-713. doi:10.1017/S0954579400006799

Davidson, A. J., Gest, S. D., \& Welsh, J. A. (2010). Relatedness with teachers and peers during early adolescence: An integrated variable-oriented and person-oriented approach. Journal of School Psychology, 48, 483-510. doi:10.1016/j.jsp.2010.08.002

De Neve, J. E. (2011). Functional polymorphism (5-HTTLPR) in the serotonin transporter gene is associated with subjective well-being: Evidence from a US nationally representative sample. Journal of Human Genetics, 56(6), 456-459. doi:10.1038/jhg.2011.39

Di Paula, A., \& Campbell, J. D. (2002). Self-esteem and persistence in the face of failure. Journal of Personality and Social Psychology, 83, 711-724. doi:10.1037//00223514.83 .3

Dijkstra, J. K., Lindenberg, S., \& Veenstra, R. (2007). Same-gender and cross-gender peer acceptance and peer rejection and their relation to bullying and helping among preadolescents: Comparing predictions from gender-homophily and goal-framing 
approaches. Developmental Psychology, 43, 1377-1389. doi:10.1037/00121649.43.6.1377

Ellis, B. J., Boyce, W. T., Belsky, J., Bakermans-Kranenburg, M. J., \& van IJzendoorn, M. H. (2011). Differential susceptibility to the environment: An evolutionaryneurodevelopmental theory. Development and Psychopathology, 23, 7-38. doi: $10.1017 / \mathrm{S} 0954579410000611$

Engels M., Colpin H., Van Leeuwen K., Bijttebier P., Van Den Noortgate W., Claes S., ... Verschueren K. (2017). School engagement trajectories in adolescence: The role of peer likeability and popularity. Journal of School Psychology, 64, 61-75. doi:10.1016/j.jsp.2017.04.006

Estell, D. B., \& Perdue, N. H. (2013). Social support and behavioral and affective school engagement: Effects of peers, parents, and teachers. Psychology in the Schools, 50, 325339. doi:10.1002/pits.21681

Faul F., Erdfelder, E., Lang, A.-G., \& Buchner, A. (2007). G*Power 3: A flexible statistical power analysis program for the social, behavioral, and biomedical sciences. Behavior Research Methods, 39, 175-191. doi:10.3758/BF03193146

Fox, E., Ridgewell, A., \& Ashwin, C. (2009). Looking on the bright side: Biased attention and the human serotonin transporter gene. Proceedings of the Royal Society B: Biological Sciences, 276, 1747-1751. doi:10.1098/rspb.2008.1788

Fredricks, J. A., Blumenfeld, P. C., \& Paris, A. H. (2004). School engagement: Potential of the concept, state of the evidence. Review of Educational Research, 74, 59-109. doi:10.3102/00346543074001059

Fredricks, J. A., \& McColskey, W. (2012). The measurement of student engagement: A 
comparative analysis of various methods and student self-report instruments. In S. L. Christenson, A. L. Reschly, \& C. Wylie (Eds.), Handbook of Research on Student Engagement (pp. 763-782). New York, NY: Springer.

Furrer, C., \& Skinner, E. (2003). Sense of relatedness as a factor in children's academic engagement and performance. Journal of Educational Psychology, 95, 148-162. doi:10.1037/0022-0663.95.1.148

Gifford-Smith, M. E., \& Brownell, C. A. (2003). Childhood peer relationships: Social acceptance, friendships, and social network. Journal of School Psychology, 41, 235284. doi:10.1016/S0022-4405(03)00048-7

Gillihan, S. J., Rao, H., Wang, J., Detre, J. A., Breland, J., Sankoorikal, G. M. V., ... Farah, M. J. (2010). Serotonin transporter genotype modulates amygdala activity during mood regulation. Social Cognitive and Affective Neuroscience, 5, 1-10. doi:10.1093/scan/nsp035

Goossens, L., van Roekel, E., Verhagen, M., Cacioppo, J., Cacioppo, S., Maes, M., \& Boomsma, D. (2015). The genetics of loneliness: Linking evolutionary theory to genome-wide genetics, epigenetics, and social science. Perspectives on Psychological Science, 10, 213-226. doi:10.1177/1745691614564878

Gunthert, K. C., Conner, T. S., Armeli, S., Tennen, H., Covault, J., \& Kranzler, H. R. (2007). Serotonin transporter gene polymorphism (5-HTTLPR) and reactivity in daily life: A daily process approach to gene-environment interaction. Psychosomatic Medicine, 69, 762-768. doi:10.1097/PSY.0b013e318157ad42

Haase, C. M., Beermann, U., Saslow, L. R., Shiota, M. N., Saturn, S. R., Lwi, S. J. ... Levenson R. W. (2015). Short alleles, bigger smiles? The effect of 5-HTTLPR on positive emotional expressions. Emotion, 15(4), 438-448. doi:10.1037/emo0000074

Hankin, B. L., Nederhof, E., Oppenheimer, C. W., Jenness, J., Young, J. F., Abela, J. R. Z., 
... Oldehinkel, A. J. (2011). Differential susceptibility in youth: evidence that 5HTTLPR x positive parenting is associated with positive affect 'for better and worse'. Translational Psychiatry, 1, 1-7. doi:10.1038/tp.2011.44

Hawker, D. S. J., \& Boulton, M. J. (2000). Twenty years' research on peer victimization and psychosocial maladjustment: A meta-analytic review of cross-sectional studies. Journal of Child Psychology and Psychiatry, 41(4), 441-445. doi:10.1111/1469-7610.00629

Heils, A., Teufel, A., Petri, S., Stöber, G., Riederer, P., Bengel, D., \& Lesch, K. P. (1996). Allelic variation of the human serotonin transporter gene expression. Journal of Neurochemistry, 66, 2621-2624. doi: 10.1046/j.1471-4159.1996.66062621.x

Homberg, J. R., \& Lesch, K. P. (2011). Looking on the bright side of the serotonin transporter gene variation. Biological Psychiatry, 69, 513-519. doi:10.1016/j.biopsych.2010.09.024

Hughes, J. N., \& Im, M. H. (2016). Teacher-student relationship and peer disliking and liking across Grades 1-4. Child Development, 87(2), 593-611. doi:10.111/cdev.12477

Jimerson, S. R., Campos, E., \& Greif, J. L. (2003). Toward an understanding of definitions and measures of school engagement and related terms. California School Psychologist, 8, 7-27. doi:10.1007/BF03340893

Johnson, W. (2007). Genetic and environmental influences on behavior: Capturing all the interplay. Psychological Review, 114, 423-440. doi:10.1037/0033-295X.114.2.423

Joiner, T. E., Katz, J., \& Lew, A. (1999). Harbingers of depressoypic reassurance seeking: Negative life events, increased anxiety, and decreased self-esteem. Personality and Social Psychological Bulletin, 25, 630-637. doi:10.1177/0146167299025005008

Joiner, T. E., Alfano, M. S., \& Metalsky, G. I. (1992). When depression breeds contempt: Reassurance seeking, self-esteem, and rejection of depressed college students by their roommates. Journal of Abnormal Psychology, 101, 165-173. doi:10.1037/0021843X.101.1.165 
Jonassaint, C. R., Ashley-Koch, A., Withfield, K. E., Hoyle, R. H., Richman, L. S., Siegler, I. C., ...Williams, R. (2012). The serotonin transporter gene polymorphism (5-HTTLPR) moderates the effect of adolescent environmental conditions on self-esteem in young adulthood: A structural equation modeling approach. Biological Psychology, 91, 111119. doi:10.1016/j.biopsycho.2012.05.004

Kamakura, T., Ando, J., \& Ono, Y. (2007). Genetic and environmental effects of stability and change in self-esteem during adolescence. Personality and Individual Differences, 42(1), 181-190. doi:10.1016/j.paid.2006.07.005

Kindermann, T. A., Zimmer-Gembeck, M. J., Duffy, A. (2010). Capturing the peer context: Common themes and synergies. Journal of Adolescence, 33, 891-895. doi: 10.1016/j.adolescence.2010.08.001

Klug, W. S., Cummings, M. R., Spencer, C. A., \& Palladino, M. A. (2010). Essentials of genetics $\left(7^{\text {th }}\right.$ ed.). Boston, MA: Benjamin Cummings.

Kretschmer, T., Sentse, M., Dijkstra, J. K., \& Veenstra, R. (2014). The interplay between peer rejection and acceptance in preadolescence and early adolescence, serotonin transporter gene, and antisocial behavior in late adolescence: The TRAILS study. Merrill-Palmer quarterly, 60, 193-216. doi:10.13110/merrpalmquar1982.60.2.0193

La Greca, A. M., \& Harrison, H. M. (2005). Adolescent peer relations, friendships, and romantic relationships: Do they predict social anxiety and depression? Journal of Clinical Child \& Adolescent Psychology, 34, 49-61.doi:10.1207/s15374424jccp3401_5

Ladd, G. W., \& Dinella, L. M. (2009). Continuity and change in early school engagement: Predictive of children's achievement trajectories from first to eight grade? Journal of Educational Psychology, 101, 190-206. doi:10.1037/a0013153

Larson, R., \& Richards, M. H. (1991). Daily companionship in late childhood and early 
adolescence: Changing developmental contexts. Child Development, 62, 284-300. doi:10.2307/1131003

Leach, L. F., Henson, R. K., Odom, L. R., \& Cagle, L. S. (2006). A reliability generalization study of the self-description questionnaire. Educational and Psychological Measurement, 66, 285-304. doi:10.1177/0013164405284030

Leary, M. R., Cottrell, C. A., \& Phillips, M. (2001). Deconfounding the effects of dominance and social acceptance on self-esteem. Journal of Personality and Social Psychology, 81, 898-909. doi:10.1037//0022-3514.81.5.898

Leary, M. R., Tambor, E. S., Terdal, S. K., \& Downs, D. L. (1995). Self-esteem as an interpersonal monitor: The sociometer hypothesis. Journal of Personality and Social Psychology, 68, 518-530. doi:10.1037/0022-3514.68.3.518

Li, Y., \& Lerner, R. M. (2011). Trajectories of school engagement during adolescence: Implications for grades, depression, delinquency, and substance use. Developmental Psychology, 47, 233-247. doi:10.1037/a00213

Loukas, A., Ripperger-Suhler, K. G., \& Horton, K. D. (2009). Examining temporal associations between school connectedness and early adolescent adjustment. Journal of Youth and Adolescence, 38, 804-812. doi:10.1007/s10964-008-9312-9

Lubbers, M. J., Van Der Werf, M. P. C., Snijders, T. A. B., Creemers, B. P. M., \& Kuyper, H. (2006). The impact of peer relations on academic progress in junior high. Journal of School Psychology, 44, 491-512. doi:10.1016/j.jsp.2006.07.005

Maassen, G. H., van Boxtel, H. W., \& Goossens, F. A. (2005). Reliability of nominations and two-dimensional methods for sociometric status determination. Journal of Applied Developmental Psychology, 26, 51-68. doi:10.1016/j.appdev.2004.10.005

Margoob, M., \& Mushtaq, D. (2011). Serotonin transporter gene polymorphism and psychiatric disorders: Is there a link? Indian Journal of Psychiatry, 53, 289-299. 
doi:10.4103/0019-5545.91901

Marsh, H. W. (1992). Self-Description Questionnaire (SDQ) II: A theoretical and empirical basis for the measurement of multiple dimensions of adolescent self-concept. Penrith, New South Wales, Australia: University of Western Sydney, SELF Research Centre.

Marsh, H. W., Plucker, J. A., \& Stocking, V. B. (2001). The Self-Description Questionnaire II and gifted students: Another look at Plucker, Taylor, Callahan, and Tomchin's (1997) "Mirror, mirror on the wall". Educational and Psychological Measurement, 61, 976996. doi: 10.1177/00131640121971608

Meyer, D. K., \& Turner, J. C. (2002). Discovering emotion in classroom research. Educational Psychologist, 37, 107-114.doi:10.1207/S15326985EP3702_5

Miller, R., Wankerl, M., Stalder, T., Kirschbaum, C., \& Alexander, N. (2013). The serotonin transporter gene-linked polymorphic region (5-HTTLPR) and cortisol stress reactivity: a meta-analysis. Molecular Psychiatry, 18, 1018-1024. doi:10.1038/mp.2012.124

Neiss, M. B., Sedikides, C., \& Stevenson, J. (2002). Self-esteem: A behavioral genetic perspective. European Journal of Personality, 16, 351-367. doi:10.1002/per.456 depression. The Lancet, 347, 731-733. doi:10.1016/S0140-6736(96)90079-3

Orth, U., Robins, R. W., \& Roberts, B. W. (2008). Low self-esteem prospectively predicts depression in adolescence and young adulthood. Journal of Personality and Social Psychology, 95, 695-708. doi:10.1037/0022-3514.95.3.695

Orth, U., Robins, R. W., \& Widaman, K. F. (2012). Life-span development of self-esteem and its effects on important life outcomes. Journal of Personality and Social Psychology, 102, 1271-1288. doi:10.1037/a0025558

Pietarinen, J., Soini, T., \& Pyhältö, K. (2014). Students' emotional and cognitive engagement as the determinants of well-being and achievement in school. International Journal of Educational Research, 67, 40-51. doi:10.1016/j.ijer.2014.05.001 
Plomin, R. (2013). Child development and molecular genetics: 14 years later. Child Development, 84(1), 104-120. doi:10.1111/j.1467-8624.2012.01757.x

Resnick, M. D., Bearman, P. S., Blum, R. W., Bauman, K. E., Harris, K. M., Jones, J., ...

Udry, J. R. (1997). Protecting adolescents from harm. Findings from the National Longitudinal Study on Adolescent Health. The Journal of the American Medical Association, 278, 823-832. doi:10.1001/jama.278.10.823

Robins, R. W., Donnellan, M. B., Widaman, K. F., \& Conger, R. D. (2010). Evaluating the link between self-esteem and temperament in Mexican origin early adolescents. Journal of Adolescence, 33, 403-410. doi:10.1016/j.adolescence.2009.07.009

Rubin, K. H., Dwyer, K. M., Booth-Laforce, C., Kim, A. H., Burgess, K. B., \& Rose-Krasnor, L. (2004). Attachment, friendship, and psychosocial functioning in early adolescence. Journal of Early Adolescence, 24, 326-356. doi:10.1177/0272431604268530

Rubin, K.H., Bukowski, W., \& Parker, J. (2006). Peer interactions, relationships, and groups. In W. Damon, R. M. Lerner, \& N. Eisenberg (Eds.), Handbook of Child Psychology. Vol. 3., Social, emotional and personality development (6 $6^{\text {th }}$ ed., pp. 571-645). New York: Wiley.

Sagayadevan, V., \& Jeyaraj, S. (2012). The role of emotional engagement in lecturer-student interaction and the impact on academic outcomes of student achievement and learning. Journal of the Scholarship of Teaching and Learning, 12(3), 1-30. Retrieved from http://files.eric.ed.gov/fulltext/EJ992115.pdf

Skinner, E., Furrer, C., Marchand, G., \& Kindermann, T. (2008). Engagement and disaffection in the classroom: Part of a larger motivational dynamic? Journal of Educational Psychology, 100, 765-781. doi:10.1037/a0012840

Skinner, E. A., Kindermann, T. A., \& Furrer, C. J. (2009). A motivational perspective on 
engagement and disaffection: Conceptualization and assessment of children's behavioral and emotional participation in academic activities in the classroom. Educational and Psychological Measurement, 69, 493-525. doi: 10.1177/0013164408323233

Skinner, E. A., \& Pitzer, J. R. (2012). Developmental dynamics of student engagement, coping, and everyday resilience. In S. L. Christenson, A. L. Reschly, \& C. Wylie (Eds.), Handbook of research on student engagement (pp. 21-44). New York, NY: Springer.

SoftGenetics. (2010). GeneMarker (Version 1.91) [Computer software]. State College, PA: SoftGenetics.

Sowislo, J. F., \& Orth, U. (2013). Does low self-esteem predict depression and anxiety? A meta-analysis of longitudinal studies. Psychological Bulletin, 139, 213-240. doi: $10.1037 / \mathrm{a} 0028931$

Spithoven, A. W. M., Bijttebier, P., Van Den Noortgate, W., Colpin, H., Verschueren, K., Van Leeuwen, K. ... Goossens, L. (2015). Adolescent loneliness and the interaction between the serotonin transporter gene (5-HTTLPR) and parental support: A replication study. PLoS One, 10, doi:10.1371/journal.pone.0133430

Sugden, K., Arseneault, L., Harrington, H., Moffit, T. E., Williams, B., \& Caspi, A. (2010). Serotonin transporter gene moderates the development of emotional problems among children following bullying victimization. Journal of the American Academy of Child \& Adolescent Psychiatry, 49, 830-840. doi:10.1016/j.jaac.2010.01.024

Swann, W. B., Jr., Rentfrow, P. J., \& Guinn, J. S. (2003). Self-verification: The search for coherence. In M. R. Leary \& J. P. Tangney (Eds.), Handbook of self and identity (pp. 367-383). New York, NY: Guilford Press.

Thomaes, S., Reijntjes, A., Orobio de Castro, B., Bushman, B. J., Poorthuis, A., \& Telch, M. 
J. (2010). I like me if you like me: On the interpersonal modulation and regulation of preadolescents' state self-esteem. Child Development, 81, 811-825. doi:10.1111/j.14678624.2010.01435.x

Vanhalst, J., Luyckx, K., Scholte, R., Engels, R., \& Goossens, L. (2013). Low self-esteem as a risk factor for loneliness in adolescence: Perceived - but not actual - social acceptance as an underlying mechanism. Journal of Abnormal Child Psychology, 41, 1067-1081. doi:10.1007/s10802-013-9751-y

van IJzendoorn, M. H., Belsky, J., \& Bakermans-Kranenburg, M. J. (2012). Serotonin transporter genotype 5HTTLPR as a marker of differential susceptibility? A metaanalysis of child and adolescent gene-by-environment studies. Translational Psychiatry, 2, e147. doi:10.1038/tp.2012.73

Viner, R. M., Ozer, E. M., Denny, S., Marmot, M., Resnick, M., Fatusi, A., \& Currie, C. (2012). Adolescence and the social determinants of health. The Lancet, 379, 1641-1652. doi:10.1016/S0140-6736(12)60149-4

Waas, G. A. (2006). Peer relationships. In G. G. Bear \& K. M. Minke (Eds.), Children's Needs III: Development, prevention, and intervention. Washington, DC: National Association of School Psychologists.

Wehlage, G. G., Rutter, R. A., Smith, G. A., Lesko, N. L., \& Fernandez, R. R. (1989).

Reducing the risk: Schools as communities of support. Philadelphia, PA: Farmer Press.

Wentzel, K. R., Wigfield, A., \& Miele, D. (2009). Handbook of motivation at school. New York, NY: Routledge.

Wray, N. R., James, M. R., Gordon, S. D., Dumenil, T., Ryan, L., Coventry, W. L., ... Martin, N. G. (2009). Accurate, large-scale genotyping of 5HTTLPR and flanking single nucleotide polymorphisms in an association study of depression, anxiety, and 
personality measures. Biological Psychiatry, 66, 468-476. doi: 10.1016/j.biopsych.2009.04.030 
Table 1

Bivariate Correlations, Means, Standard Deviations, and Minimum and Maximum Values of the Main Study Variables

\begin{tabular}{|c|c|c|c|c|c|c|c|}
\hline Variables & 1 & 2 & 3 & 4 & 5 & 6 & 7 \\
\hline 3. Peer Acceptance & -.01 & .04 & 1 & & & & \\
\hline 4. Peer Rejection & .04 & .00 & $-.37 * * *$ & 1 & & & \\
\hline 6. Emotional School Engagement & $-.14 * * *$ & $.08^{*}$ & .04 & $-.10 * *$ & -.01 & 1 & \\
\hline 7. Global Self-Esteem & $-.07 *$ & -.06 & .06 & $-.12 * * *$ & .00 & $.39 * * *$ & 1 \\
\hline$M$ & 1.91 & 1.49 & .07 & -.05 & .67 & 2.91 & 4.71 \\
\hline Max & 3.00 & 2.00 & 3.47 & 5.00 & 1.00 & 4.00 & 6.00 \\
\hline
\end{tabular}

Note. Gender was dummy coded $(0=$ boy, $1=$ girl $) ; 5$-HTTLPR $=$ serotonin transporter gene, dummy coded $(0=$ homozygote long carriers, $1=$ short carriers)

$* p<.05 . * * p<.01 . * * * p<.001$ 
Table 2

Hierarchical Multiple Regression of Global Self-Esteem and Emotional School Engagement on Main and Interaction Variables of Genes and

Environments

\begin{tabular}{|c|c|c|c|c|c|c|c|c|c|c|}
\hline \multirow[b]{2}{*}{ Predictor variable } & \multicolumn{5}{|c|}{ Global Self-Esteem } & \multicolumn{5}{|c|}{ Emotional School Engagement } \\
\hline & $B$ & $S E B$ & $\beta$ & $R^{2}$ & $\Delta R^{2}$ & $B$ & $S E B$ & $\beta$ & $R^{2}$ & $\overline{\Delta R^{2}}$ \\
\hline \multicolumn{11}{|l|}{ Model 1: Peer Acceptance } \\
\hline \multicolumn{11}{|l|}{ Step 1} \\
\hline Grade & -0.06 & 0.03 & -.06 & & & -0.13 & 0.03 & $-.16 * * *$ & & \\
\hline \multirow[t]{2}{*}{ Gender } & -0.07 & 0.05 & -.04 & & & 0.14 & 0.04 & $.10 * *$ & & \\
\hline & & & & $.01 *$ & & & & & $.03 * * *$ & \\
\hline \multicolumn{11}{|l|}{ Step 2} \\
\hline Grade & -0.06 & 0.03 & -.06 & & & -0.13 & 0.03 & $-.16^{* * *}$ & & \\
\hline Gender & -0.07 & 0.05 & -.04 & & & 0.13 & 0.04 & $.10 * *$ & & \\
\hline Peer acceptance & 0.04 & 0.02 & .06 & & & 0.02 & 0.02 & .04 & & \\
\hline \multirow[t]{2}{*}{ 5-HTTLPR } & 0.02 & 0.05 & .01 & & & -0.01 & 0.04 & -.00 & & \\
\hline & & & & & .00 & & & & & .00 \\
\hline \multicolumn{11}{|l|}{ Step 3} \\
\hline Grade & -0.06 & 0.03 & -.06 & & & -0.13 & 0.03 & $-.16 * * *$ & & \\
\hline Gender & -0.07 & 0.05 & -.05 & & & 0.13 & 0.04 & $.10 * *$ & & \\
\hline 5-HTTLPR & 0.03 & 0.03 & .04 & & & 0.05 & 0.03 & .08 & & \\
\hline Peer acceptance x 5HTTLPR & 0.02 & 0.05 & .02 & & & -0.04 & 0.04 & -.05 & & \\
\hline
\end{tabular}




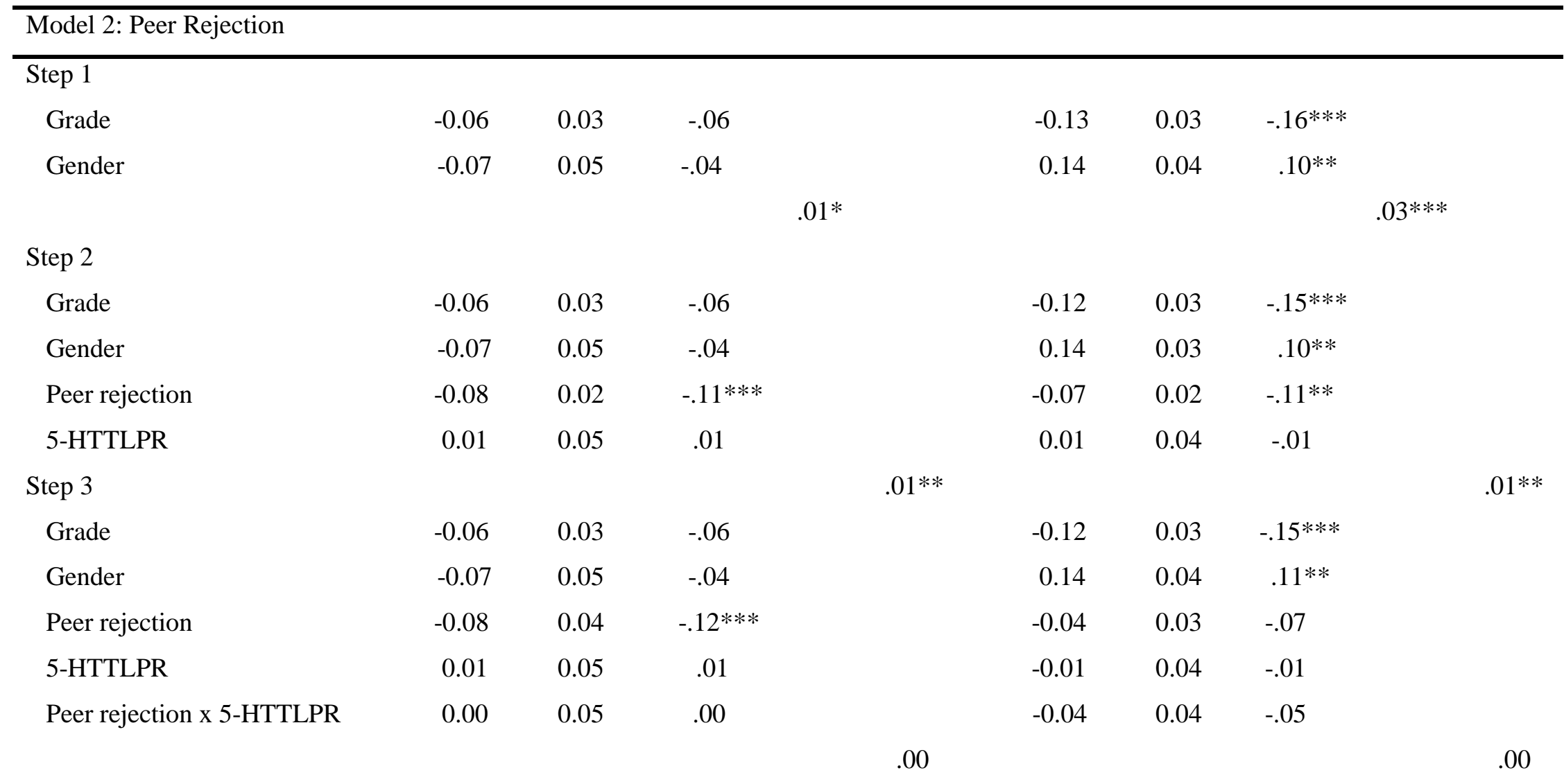

Note. $N=1,053$. In all analyses, gender $(0=$ boy, $1=$ girl $)$ and grade are controlled for; 5 -HTTLPR $=$ serotonin transporter gene, dummy coded $(0=$ homozygote long carriers, $1=$ short carriers $) ; \beta=$ standardized regression coefficient

$* p<.05 . * * p<.01 . p<.001$. 